\title{
The sealant restoration: indications, success and clinical technique
}

\author{
D. C. Hassall,' and A. C. Mellor, ${ }^{2}$
}

\begin{abstract}
In this paper we have considered the available literature which demonstrates that sealant restorations perform at least as well as amalgam restorations and are more conservative. Success depends on retention of the overlying sealant and if this is fully retained it is unlikely that any residual caries will progress. The diagnosis of occlusal caries and indications for sealant restorations are discussed and the clinical technique is described. We have concluded that sealant restorations are the optimum restoration in small and discrete occlusal cavities.
\end{abstract}

and properly illuminated. The use of magnification may also aid diagnosis. The use of a probe should be restricted to the removal of plaque or food debris. Lesions should not be probed as has been advocated as this may cause cavitation. ${ }^{1}$ Drying the tooth significantly improves diagnosis by driving fluid out of the micropores of demineralized enamel, the affected area appearing a matt white in contrast to the gloss of normal enamel.

Dark staining is not a criteria for diagnosis of caries alone, but loss of normal enamel transparency surrounding a pit indicates the presence of demineralization and may indicate a developing lesion.

Bitewing radiographs are a pre-requisite when considering a sealant restoration. These should show no evidence of interproximal caries which may indicate that a more extensive restoration is required. It should be considered that the actual size of the lesion is usually larger than the radiographic image implies. ${ }^{2}$ Lesions suitable for sealant restoration placement may be tactile and radiographic examination.

Visual examination should be undertaken with the teeth thoroughly air dried

\footnotetext{
$\overline{1^{*} \text { Private Restorative, Prosthodontic, Periodontal and }}$ Endodontic Specialist; ${ }^{2}$ Senior Lecturer in Primary

Dental Care, University Dental Hospital of Manchester

${ }^{*}$ Correspondence to: Dominic Hassall, 28 Cloister Crofts, Leamington Spa, Warwickshire CV32 6QQ email:dominichassall@yahoo.com REFEREED PAPER

Received 20.12.00; Accepted 23.03.01

(C) British Dental Journal 2001; 191: 358-362
}

\section{In brief}

This article discusses:

- Indications for sealant restorations

- The diagnosis of occlusal caries

- Clinical procedures for sealant restorations

- Success rates for sealant restorations those just into dentine. Bitewings are of great importance in the diagnosis of occlusal caries particularly with the advent of 'hidden caries' or the 'fluoride syndrome'. This was first described by Millman in the early 1980s and is the term used to describe occlusal dentine caries that is missed on visual examination but detected radiographically or when a fissure biopsy is undertaken. ${ }^{3}$ It is thought to be associated with the use of fluoride toothpaste, community fluoridation and topical fluoride therapies. There is still controversy regarding the existence of 'hidden caries' but the general consensus in the literature is that it does exist as an entity. 4

Fibre-optic transillumination may also be of benefit in diagnosing occlusal and interproximal caries. Continuing developments are being made in the concept of electrical impedance ${ }^{5}$ and laser fluoresence (Diagnodent, $\mathrm{KaVo}$ ) appears to have potential in detecting and monitoring occlusal caries.

\section{Success rates for sealant restorations}

One of the major problems when considering the success rates of sealant restoratons is the variation in techniques and materials used. There are also few studies directly comparing sealant restorations with conventional amalgam restorations.

Short term studies indicate a high degree of success for sealant restorations. ${ }^{6-15}$ However, longer term studies appear to indicate that success is less predictable (Table1). ${ }^{16-21}$ For direct comparison of sealant restoration studies it is necessary to define success as $100 \%$ retention and no caries present in the tooth.

However, presenting the studies in this manner can give a misleading picture and it is necessary to consider a number of the studies in more detail.

Mertz-Fairhust et al. ${ }^{21}$ reported 9-year results comparing three types of restoration: unsealed amalgams, amalgams with sealant and composite with sealant. Twenty-eight per cent of the sealants were fully retained in the composite and sealant type, a further 
$41 \%$ were partially retained and only $16 \%$ of the sealant restorations failed because of caries. What is particularily interesting is that restorations were placed over carious lesions after minimal preparation and that the carious lesions did not progress beneath intact sealed restorations. The clinical performance of the composite and sealant type was superior to the other restoration types and the authors concluded that 'sealed restorations are superior to traditional amalgam restorations'.

In a noteworthy study Welbury et al. ${ }^{21}$ compared minimal composite restorations with amalgam restorations over 5 years. While only $26 \%$ of the sealant restorations were fully retained and caries free, only $2 \%$ of the restorations failed because of caries associated with the restoration. There was no significant difference in median survival time between the amalgam and sealant restorations, and it was found that on average amalgam restorations occupied $25 \%$ of the occlusal surface of the tooth, while minimal composite restorations occupied 5\%.

Houpt et al. ${ }^{20}$ in a 9 -year study demonstrated that $54 \%$ of sealant restorations had completely retained sealants with $25 \%$ sustaining partial loss. Occlusal caries was recorded in $25 \%$ of restorations in which there was sealant loss but there was no occlusal caries when the sealant was fully retained.

The consensus from the studies is that sealant restorations perfom at least as well as conventional amalgams and are far more conservative of tooth tissue. It is also apparent that the longevity of the sealant restoration is dependent on the complete retention of the overlying sealant.

If the overlying sealant is fully retained then recurrent caries or progression of caries beneath the restoration is negligible. This is consistent with studies of caries progression beneath fissure sealants which indicate that it does not progress beneath intact sealants. ${ }^{22-27}$

Consequently if a sealant restoration is placed, the dentist has a duty of care to ensure that the retention of the sealant is regularly reviewed and repaired or replaced as necessary. In addition bitewing radiographs should be taken at appropriate

\begin{tabular}{|c|c|c|}
\hline Study & $\begin{array}{c}\text { Duration } \\
\text { (years) }\end{array}$ & $\begin{array}{c}\text { Success* } \\
(\%)\end{array}$ \\
\hline 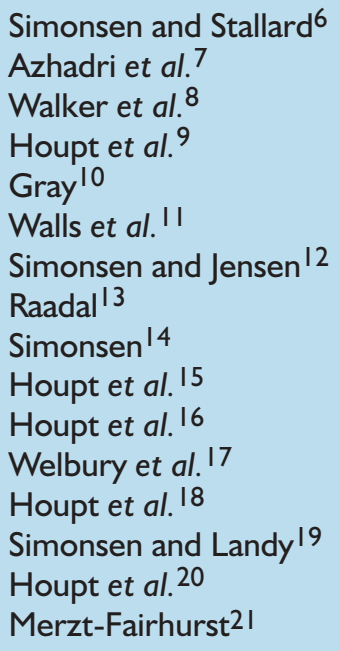 & $\begin{array}{l}1.0 \\
1.0 \\
1.25 \\
1.5 \\
2 \\
2.0 \\
2.5 \\
2.5 \\
3.0 \\
3.0 \\
4.0 \\
5.0 \\
6.5 \\
7.0 \\
9.0 \\
9.0\end{array}$ & $\begin{array}{c}100 \\
86 \\
82 \\
91 \\
67-97 \\
97 \\
96 \\
84 \\
99 \\
77 \\
64 \\
26 \\
65 \\
90 \\
54 \\
28\end{array}$ \\
\hline \multicolumn{3}{|c|}{ * Complete sealant retention and tooth caries free } \\
\hline
\end{tabular}

intervals to check there is no further caries progression.

\section{Clinical procedure}

It is useful to mark occlusal contacts prior to preparation. This will assist in the final decision as to whether a sealant restoration is appropriate.

If it is anticipated that the cavity may be of moderate size then local anaesthesia will be necessary. Ideally the tooth is isolated with rubber dam (Fig. 1) This not only assists in moisture control but also aids visualisation and cross-infection control.

What has been termed the fissure or enamel biopsy is then undertaken with a small diameter bur such as a tungsten carbide long pear (Jet 330, Beavers Dental). This involves cutting a minimal opening to the depth of the enamel-dentine junction sufficient to determine whether the caries is more widespread (Fig. 2). All suspect areas of the fissure system should be explored. ${ }^{28}$ In this case there is dark staining and associated opacity in the central pit of the tooth.
If the carious lesion extends beyond the enamel-dentine junction (Fig. 2) caries removal should be continued, limiting removal to carious tissue only (Fig. 3). Probably the most reliable method of caries assessment remains surface colour, structure and hardness, and the cavity is accordingly assessed. ${ }^{29}$

Where there is restricted access it is important to thoroughly inspect the cavity to ensure that caries removal is complete (Fig. 4). The cavity is then assessed to determine whether a sealant restoration is indicated. More extensive caries may necessitate an amalgam restoration or posterior composite.

Once the restorative has been placed the restoration and remaining fissures can be fissure sealed. This may involve etching of the enamel if this has not already been undertaken as part of the composite bonding procedure.

Finally the rubber dam is removed, occlusal contacts checked and any interferences removed (Fig. 5). 


\section{PRACTICE \\ restorative dentistry}

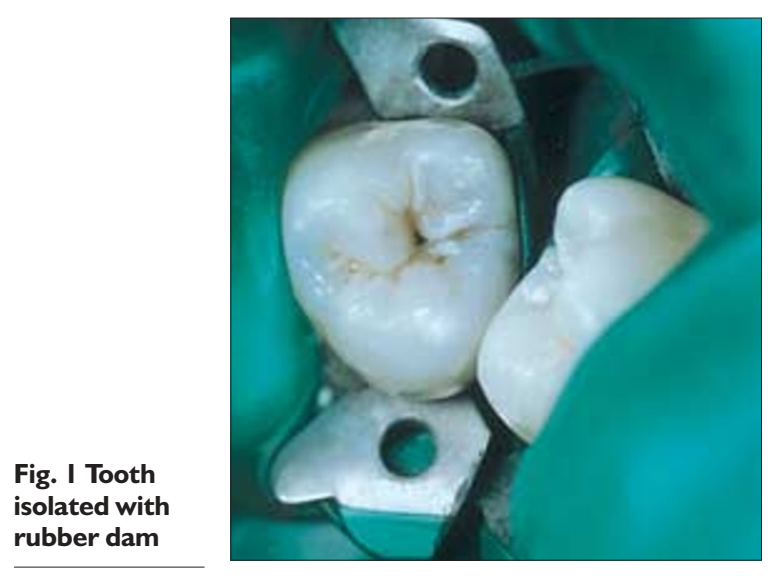

Fig. 2 Caries

extending

beyond the enamel dentine junction

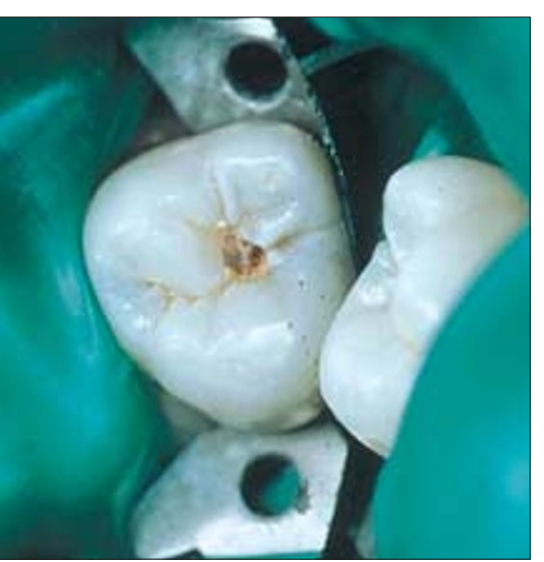

Fig. 4 Completed minimal cavity preparation

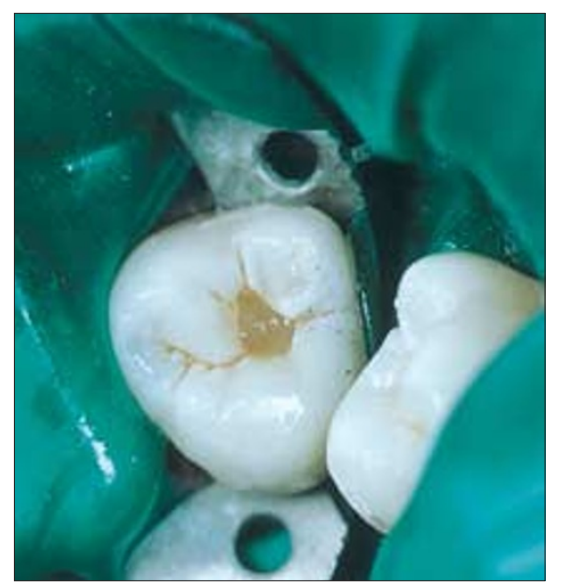

A number of restorative techniques and materials are available for the restoration of the cavity. At present four types of sealant restoration are available under the NHS GDS fee scale:

1. GDS Item 14e1: Fissure sealant alone

2. GDS Item 14e2: Fissure sealant with composite resin

3. GDS Item 14e3: Fissure sealant with glass ionomer

4. GDS Item 14e4: Fissure sealant with both composite resin and glass ionomer.

If the caries does not extend beyond the level of the enamel dentine junction fissure sealant only may be required. If however the cavity is of a larger size a number of options exist, involving the use of composite resin, glass ionomer or both materials in combination.

The indications for the use of the four

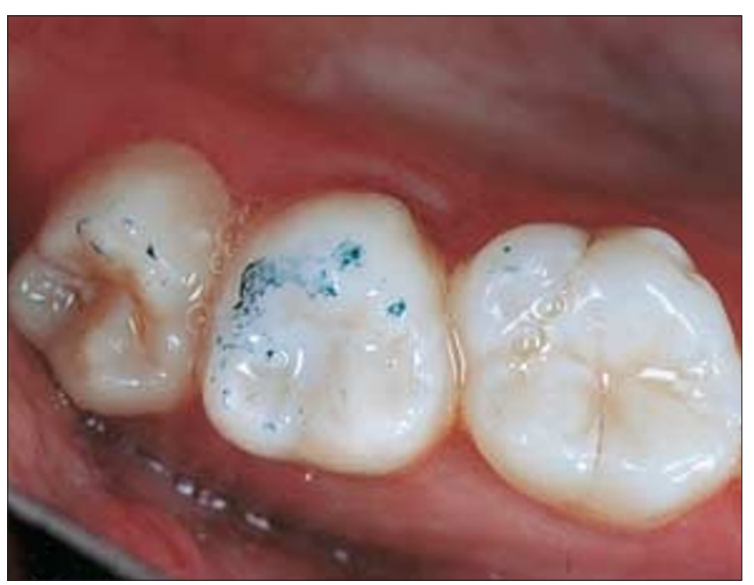

Fig. 5 Checking occlusion of completed sealant restoration 
type of sealant restorations has been summarised by Paterson et al. (Table 2). ${ }^{30}$

It is apparent from Table 2 that there are a variety of restoratives available for use in the sealant restoration technique. The exact choice of material may often be a matter of operator preference.

The use of glass ionomer may confer advantages with regard to chemical bonding with enamel and dentine, fluoride release and possible reduction in microleakage. ${ }^{31-33}$

A number of recently introduced materials such as the 'packable' composites (Prodigy, Kerr; Solitaire 2, Heraeus Kulzer; Filtek P60, 3M) are available which may offer easier handling than conventional composites. The authors have also found the use of coated 'non-stick' composite instruments useful for posterior composite placement and adaptation (Fig. 6). These instruments (Ash) are available with a range of tips which facilitate more easy access and packing (Fig. 7).

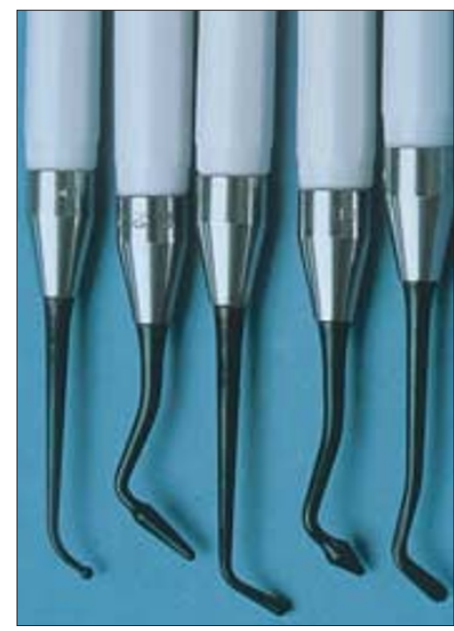

Fig. 6 'Non stick' composite instruments

More recently introduced 'flowable composites' (Revolution, Kerr) may also prove to be beneficial in restoring cavities in which there is restricted access. ${ }^{34}$ However physical properties are inferior to conventional composites and they would appear inappropriate for larger posterior cavities or where there are heavy occlusal contacts.

\begin{tabular}{|c|c|}
\hline Type of sealant restoration & Indications \\
\hline $\begin{array}{l}\text { Type I } \\
\text { Fissure sealant alone }\end{array}$ & $\begin{array}{l}\text { Stained and decalcified fissure } \\
\text { No radiographic sign of dentine } \\
\text { involvement } \\
\text { Less than two other carious lesions } \\
\text { in mouth }\end{array}$ \\
\hline $\begin{array}{l}\text { Type } 2 \\
\text { Composite plus sealant }\end{array}$ & $\begin{array}{l}\text { Stained and decalcified fissure } \\
\text { More than two other carious } \\
\text { lesions in mouth } \\
\text { Enamel biopsy shows lesion confined } \\
\text { to enamel }\end{array}$ \\
\hline $\begin{array}{l}\text { Type } 3 \\
\text { Glass-ionomer cement plus } \\
\text { sealant }\end{array}$ & $\begin{array}{l}\text { Enamel biopsy indicated } \\
\text { Cavity in dentine with minimal } \\
\text { lateral spread } \\
\text { Margins not in occlusal contact }\end{array}$ \\
\hline $\begin{array}{l}\text { Type } 4 \\
\text { Laminate restoration }\end{array}$ & $\begin{array}{l}\text { Enamel biopsy indicated } \\
\text { Lesion in dentine with lateral spread } \\
\text { along EDJ } \\
\text { Cavity margins in occlusal contact }\end{array}$ \\
\hline Amalgam restoration & $\begin{array}{l}\text { Enamel biopsy indicated } \\
\text { Large radiolucency in dentine } \\
\text { Significant lateral spread along EDJ } \\
\text { Few fissures remaining surrounding } \\
\text { cavity }\end{array}$ \\
\hline
\end{tabular}

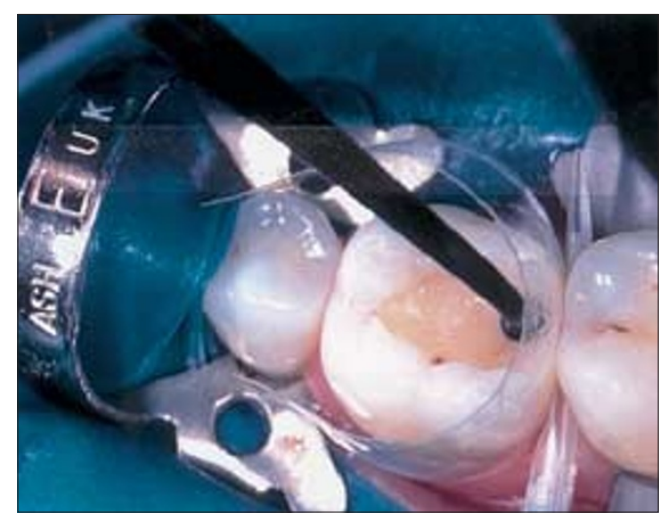

Fig. 7 Adaptation of composite in a large posterior cavity 
With minimally invasive techniques such as air abrasion and chemomechanical caries removal $^{35-37}$ materials such as the flowable composites may allow easier restoration placement where access is restricted.

\section{Conclusions}

Whilst the success of larger posterior composites appears to be inferior to amalgam ${ }^{38}$ success rates for sealant restorations are comparable to those of amalgam restorations but with the advantage that they are less invasive and hence sound tooth tissue is not removed.

Dentist concerns regarding the reported success of sealant restorations appear to be largely unsupported by longevity studies. Possible fears over incomplete caries removal also appear to be unwarranted, with caries appearing not to progress beneath intact sealants. Potential problems regarding the marginal shrinkage of composites and recurrent caries may be addressed by using glass ionomer in the technique. The costeffectiveness of the procedure may be influenced by the re-introduction of a fee-for-service element into the capitation payment system for children's dentistry.

The use of the sealant restoration should be encouraged because it represents a tooth preserving procedure, producing a more durable restoration with the added benefit of protecting the remaining fissure pattern from carious attack. It may have the potential to improve the prognosis of a tooth in 'the repeat restoration cycle. ${ }^{39}$ It is apparent however that the dentist has a duty of care to ensure that the sealant restoration is regularly reviewed and maintained to ensure continued success.

The authors would like to thank the dentists who participated in the study and the Dental Practice Board for their co-operation. The assistance of the Department of Medical and Dental Illustration at Leeds Dental Institute is appreciated. The funding of the Department of Health is acknowledged, but the views expressed are those of the authors.

1 Radike A W. Criteria for diagnosis of dental caries. Proceedings of the Conference on the Clinical Testing of Cariostatic Agents. Chicago, American Dental Association, 1972. pp87-88.

2 Gwinnett A J. A comparison of proximal carious lesions as seen by clinical radiography, contact microradiography and light microscopy. J Am Dent Assoc 1971; 83: 10781080.
3 Millman C K. Fluoride syndrome. Br Dent J 1985; 154: 341 .

4 Ricketts D, Kidd E, Weerheijm K, Hans de Soet. Hidden caries:What is it? Does it exist? Does it matter? Int Dent J 1997; 47: 259-265.

5 Longbottom C, Huysmans M-C D N Y, Pitts N B, Loss P, Bruce P G. Detection of dental decay and its extent using a.c. impedance spectroscopy. Nat Med 1996; 2: 235-237.

6 Simonsen R J, Stallard R E. Sealantrestorations utilizing a dilute filled composite resin: one year results. Quintessence Int 1977; 23: 307-315

7 Azhdari S, Sveen O B, Buonocore M G. Evaluation of a restorative preventive technique for localized occlusal caries. J Dent Res 1979; 58 (special issue A): 330 Abstract 952.

8 Walker J D, Jensen M E, Pickham J R. A clinical review of preventive resin restorations. ASDCJ Dent Child 1990; 57: 257-259.

9 Houpt M, Eidelman E, Shey Z et al. Occlusal restoration using fissure sealant instead of 'extension for prevention', eighteen month results. J Dent Res 1982; 61: 214 Abstract 324.

10 Gray G B. An evaluation of sealant restorations after 2 years. Br Dent J 1999; 186: 569-575.

11 Walls A W G, Murray J J, McCabe J F. The management of occlusal caries in permanent molars. A clinical trial comparing a minimal composite restoration with an occlusal amalgam restoration. Br Dent J 1988; 164: 288-292.

12 Simonsen R J, Jensen M E. Preventive resin restorations utilizing a diluted filled composite resins: 30 months results. J Dent Res 1979; 58(special issue A): 330(abstract No.952).

13 Raadal M. Follow-up study of sealing and filling with composite resins in the prevention of occlusal caries. Community Dent Oral Epidemiol 1978; 6: 176-180.

14 Simonsen R J. Preventive resin restorations. J Am Dent Assoc 1980; 100: 535-539.

15 Houpt M, Eidelman E, Shey E Z. Occlusal restoration using fissure sealant instead of 'extension for prevention'. ASCD J Dent Child 1984; 51: 270-273.

16 Houpt M, Eidelman E, Shey E Z. Occlusal composite restorations: 4 year results. J Am Dent Assoc 1985; 110: 351-353.

17 Welbury R R, Walls A G W, Murray J J, McCabe $J$ F. The management of occlusal caries in permanent molars. A 5-year clinical trial comparing a minimal composite with an amalgam restoration. Br Dent J 1990; 169: 361-366.

18 Houpt M, Fuks A, Eidelman E. Composite/ sealant restoration: 6.5 year results. Paed Dent 1988; 10: 304-306.

19 Simonsen R J, Landy N A. Preventive Resin Restorations: fracture resistance and 7-year clinical results. J Dent Res 1984; 63(special issue): 261 (abstract No.175).

20 Houpt M, Fuks A, Eidelman E. The preventive resin (composite resin/sealant) restoration: Nine-year results. Quintessence Int 1994; 25 : 155-159.

21 Mertz-Fairhurst E J, Adair S M, Sams D R et al. Cariostatic and ultraconservative sealed restorations: Nine-year results among children and adults. J Dent Child 1995; 62: 97-107.

22 Handleman S L, Buonocore M G, Hesek D J. A preliminary report on the effect of fissure sealant on bacteria in dental caries. J Prosthet Dent 1972; 27: 390-392

23 Handleman S L, Washburn F, Wopperer P. Two-year report of sealant effect on bacteria in dental caries. J Am Dent Assoc 1976; 93: 967-970.

24 Mertz-Fairhurst E J, Schuster G S, Williams J E, Fairhurst C W. Clinical progress of sealed and unsealed caries. Part 1: Depth changes and bacterial counts. J Prosthet Dent 1979; 42: 521-526.

25 Handleman S L. Effect of sealant placement on occlusal caries progression. Clin Preventive Dent 1982; 4: 11-16.

26 Mertz-Fairhurst E J, Schuster G S, Fairhurst C W. Arresting caries by sealants: results of a clinical study. J Am Dent Assoc 1986; 112 : 194-197.

27 Swift E J. The effect of sealants on dental caries: a review. J Am Dent Assoc 1988; 116: 700-704.

28 Paediatric Dentistry-UK. National Guidelines and Policy Documents 1999. Dental Practice Board. Management of the stained fissure in the first permanent molar. 33-36.

29 Kidd E A M, Joyston-Bechal S, Beighton D. Microbiological validation of assessment of caries activity during cavity preparation. Caries Res 1993; 27: 402-408.

30 Paterson R C, Watts A, Saunders W P, Pitts N B. Modern concepts in the diagnosis and treatment of fissure caries. London: Quintessence Books, 1991.

31 Wilson A D, Prosser H J, Powis D M. Mechanism of adhesion of polyelectrolyte cements to hydroxyapatite. J Restorative Dent 1983; 63: 590-595.

32 Swartz M L, Phillips R W, Clark H E. Long term fluoride release from glass ionomer cements. $J$ Dent Res 1984; 63: 158-160.

33 Arcoria C J, Fisher M A, Wagner M J. Microleakage in alloy-glass ionomer lined amalgam restorations after thermocycling. J Oral Rehab 1991; 18: 9-14.

34 Unterbrink G L, William H, Liebenberg B S C. Flowable composites as 'filled adhesives': Literature review and clinical recomendations. Quintessence Int 1999; 30: 249-255.

35 Christensen G J. Air abrasion tooth cutting: state of the art. J Am Dent Assoc 1998; 129: 484-487

36 Horiguchi S, Yamada T, Inokoshi S, Tagami J. Selective caries removal with air abrasion. Operative Dent 1998; 23: 236-243.

37 Hannig M. Effect of Carisolv solution on sound, demineralised and denatured dentinean ultrastructural investigation. Clin Oral Investigation 1999; 3: 155-159.

38 Collins C J, Bryant R W, Hodge K-L V. A clinical evaluation of posterior composite resin restorations:8-year findings. J Dent 1998; 26: 311-317.

39 Elderton R J. Treating restorative dentistry to health. Br Dent J 1996; 181: 220-225. 